\title{
How Brazilian students conceptualize the experience of learning German for academic purposes
}

http://dx.doi.org/10.11606/1982-88371928124

\begin{abstract}
The present study aims to investigate how foreign language learners at the German for Academic Purposes (GAP) program at a Brazilian federal university interact in their mother tongue about their motivations to learn a foreign language as well as their motivations to participate in study abroad programs. Data were collected using focus group methodology with three focus groups of six students each (A1, A2 and B1 levels). We chose to analyze the A1 group. We conducted metaphor-led discourse analysis of the data in order to examine metaphors and metonymies, which emerged in the focus group interactions. We were able to identify the presence of systematic metaphors such as learning is hard work and learning is jumping hurdles, intertwined with conceptual metaphors such as education is a journey and difficulties are weights, which point at the motivation for learning verbalized by Brazilian foreign language learners who took part in the study.
\end{abstract}

Keywords: Cognitive Linguistics; Applied Linguistics; German for Academic Purposes

Resumo: Este estudo tem como objetivo investigar como aprendizes de língua estrangeira no programa de Alemão para Fins Acadêmicos (AFA) em uma universidade federal brasileira interagem em sua língua materna sobre suas motivações para aprender uma língua estrangeira, bem como sua motivação para participar de programas de intercâmbio. Os dados foram coletados usando a metodologia de grupo focal com três grupos de seis estudantes cada (níveis A1, A2 e B1). Analisamos o grupo de A1. Conduzimos uma análise do discurso à luz da metáfora nos dados para examinar as metáforas e metonímias que surgiram nas interações dos grupos focais. Pudemos identificar a presença de metáforas sistemáticas como aprendizagem é trabalho duro $\mathrm{e}$ aprendizagem é pular barreiras, imbricadas com metáforas conceptuais como educação é uma viagem e dificuldades são peso, que apontam para a motivação de aprendizagem verbalizada pelos participantes desse estudo.

Palavras-chave: Linguística cognitiva; Linguística Aplicada; alemão para fins acadêmicos

\footnotetext{
${ }^{1}$ Universidade Federal de Minas Gerais, Faculdade de Letras, Av. Antônio Carlos, 6.627, 31270-901, Belo Horizonte, MG, Brasil. E-mail: lucianeufmg@ gmail.com.

Pesquisa realizada com apoio da Coordenação de Aperfeiçoamento de Pessoal de Nível Superior CAPES (grant Bex 1825/14-3).
} 


\section{Introduction}

Metaphors and metonymies are everywhere (LAKOFF; JOHNSON 2003), permeating the daily discourses in society, expressed in a variety of forms: verbally, in images and in gestures. They are both a cognitive and a discursive device, which enable us to conceptualize our experiences. In a previous study, when asked about the experience of learning German as a foreign language, students enrolled in the Foreign Language Program at the Faculty of Letters at the Federal University of Minas Gerais, Brazil, replied using some very interesting metaphors and similes, such as "to know German is like eating a cake with topping," and "Not knowing German is like not missing something you haven't even tasted, but you might enjoy,"3 whose underlying conceptual metaphor is LEARNING IS FOOD. Other metaphors which appeared in students' speech during the interviews in that preliminary study were "Knowing German is like traveling to an unknown place", "Learning German is weird. You feel lost at the beginning, but then you get on the right track", 5 whose motivating cognitive metaphor is LEARNING IS A JOURNEY. Among the students' answers were also some metonymies, for instance "to speak German is to be inside, whereas if you don't speak German, you are outside" (FERREIRA 2014), whose underlying motivation is the CONTAINER image-schema (JOHNSON 1987).

Starting from these preliminary findings, the present study deals with empirical data from undergrad students, all Brazilian Portuguese native speakers, learners of German for Academic Purposes pursuing to acquire language proficiency in order to take part in the exchange programs offered by the Federal University of Minas Gerais, Brazil, Minas Mundi ${ }^{6}$ and Ciência Sem Fronteiras ("Science without Borders"). ${ }^{7}$ In the present study, we aim to observe the way students talk about their motivations for learning German for Academic Purposes, how they explain their learning process, i.e. how and where they learn

\footnotetext{
${ }^{2}$ Original in Brazilian Portuguese: "Saber alemão é como comer um bolo com cobertura".

${ }^{3}$ Original in Brazilian Portuguese: "Não saber alemão é como não sentir falta de algo que você ainda não provou para poder gostar".

${ }^{4}$ Original in Brazilian Portuguese: "Saber alemão é como viajar para um lugar desconhecido".

${ }^{5}$ Aprender alemão é engraçado. "Você fica perdido no começo, mas depois começa a se virar".

${ }^{6}<$ https://www.ufmg.br/dri/programas/aluno-da-ufmg/editais-anteriores/minas-mundi>. Acesso em 01 mai. 2016

${ }^{7}<$ http://www.cienciasemfronteiras.gov.br/web/csf $>$ Acesso em 01 mai. 2016
} 
and what are their expectations concerning the international exchange program and their stay at a university in Germany. An emic perspective has been therefore adopted. Cameron (2003) has pointed out the importance of metaphor as a pedagogical tool for description, explanation, exemplification, restatement, and evaluation. It has also been claimed that metaphor has a meta-discursive function (LOW ET AL. 2008). The present study is an attempt to show how all these notions appear in the learners' speech.

Although there are some studies on teachers' metaphors about learning and teaching (CAMERON 2003; EdWARdS ET AL. 2004; LitTLEMORE; LOW 2006), there are not many studies available which show the metaphors used by the learners themselves describing their experiences from an emic perspective (for a study from an emic perspective, see Paiva 2008). Most studies on this topic were carried out with learners of English as a Foreign/ Second Language (PAiva 2008; Littlemore ET AL. 2011; LOW ET AL. 2008; FAlCK 2012; FERREIRA 2007; SILVA 2013; GOMES 2015). Some studies investigating students' experience on learning a foreign language other than English - Norwegian, for example (GOLDEN 2012) - were conducted using other research methodology. Golden's study, for instance, employs corpus linguistics methodology.

In this study, our aim is to investigate the discourse of German for Academic Purposes learners' from an experientialist perspective, where learners are regarded as part of the environment and in constant interaction with it. Participants describe their experience of learning German as a process, where they move through paths, journeys, where they interact with the learning contents and where they project their FL learning experiences and its results in the future, when they will be living these new academic life experiences in Germany, i.e. studying at a German university and getting in touch with a new environment.

The German for Academic Purposes program, whose acronym is $\mathrm{AFA},{ }^{8}$ was introduced at the Federal University of Minas Gerais (UFMG), Brazil, by a joint initiative of the Faculty of Letters and the university's International Relations Office ${ }^{9}$ (DRI) in

\footnotetext{
${ }^{8}$ AFA stands for Alemão para Fins Específicos, which is the translation of German for Specific Purposes into Brazilian Portuguese.

${ }^{9}$ Direção de Relações Internacionais (<www.ufmg.br/dri〉, acesso em 01 mai. 2016). 
2013. ${ }^{10}$ It has received the support of the German Academic Exchange Service (DAAD) since its beginning as well. The strong motivation of the learners of the German for Academic Purposes program at $\mathrm{UFMG}^{11}$ - who belong to different areas of study, mainly Engineering and Humanities - enhanced by the possibility of taking part on the exchange programs jointly sponsored by CAPES and DAAD, ${ }^{12}$ as well as the high standard of research at German Universities, seem to function as a magnet for Brazilian students in the academy.

In the specific case of UFMG, students have been taking part in the University sponsored program Minas Mundi ${ }^{13}$ and, until 2016, they took part in the Science without Boarders (SWB) program. ${ }^{14}$ The main goal of the SWB program was to promote the consolidation and expansion of science, technology and innovation in Brazil by means of international exchange and mobility. Heitz (2013: 112) points out that 2,988 Brazilian students have studied at German Universities sponsored by the SWB program since $2011 .^{15}$ Due to budget cuts in Brazil, the SWB program has been frozen since 2015.

At UFMG, the International Relations Office (DRI), along with the Faculty of Letters (FALE), and with support of the German Service for Academic Exchange (DAAD) ${ }^{16}$ offered a free introductory course called German for Academic Purposes (AFA) for 25 students in November 2013. 180 students registered for the AFA program, hence we offered two levels for 50 students. In 2015, 34 students from undergrad and grad programs at UFMG attended the AFA program (B1, B1+ and B2 levels). ${ }^{17}$ However, the dropout rate was high and only 13 students finished. Hence, we already have data available, which can

\footnotetext{
${ }^{10}$ As a member of the German Department, I was then invited by the International Relations Office to introduce and coordinate the AFA activities, which lead to the development of the German without Boarders program (in Portuguese "Alemão sem Fronteiras", called AsF) at UFMG, sponsored by the Brazilian Ministery of Education (MEC) as part of the broader program Idioms without Boarders (IsF).

${ }^{11}$ For data on the motivation of German as a Foreign Language students at UFMG see MERICKA (2015).

${ }^{12}$ DAAD also sponsors different programs separately.

${ }^{13}$ <www.ufmg.br/dri/programas/aluno-da-ufmg/editais-anteriores/minas-mundi> Acesso em 01 mai. 2016

${ }^{14}<$ http://www.cienciasemfronteiras.gov.br/web/csf>Acesso em 01 mai. 2016

${ }^{15}$ According to the SWB website.

${ }^{16}$ Through a CAPES/DAAD sponsored project, which I coordinate since 2013, AFA has received partly the support of a German Teaching Assistant.

${ }^{17}$ According to the Common European Frame of Reference.
} 
help us evaluate the impact such programs have had as an incentive for students taking part in the AFA program.

In the next section, some previous work on metaphor/ metonymy and Foreign Language Learning (FLL) is discussed.

\section{Research on metaphor/metonymy and Foreign Language Learning}

In an investigation on metaphor and the curriculum, Lawton (1984) classifies curriculum metaphors based on Lakoff and Johnson (1980) categories, as follows: (a) a curriculum as a building operation; (b) as food; (c) as a plant, since we talk about the core of the curriculum; (d) as a product, for instance curriculum making; (e) as a commodity, for instance Paulo Freire's banking metaphor (see BERBER SARDINHA 2007).

On her study on language learning histories (LLHs), Paiva (2008) investigates personal reflections in LLHs, framed by the 'landscape of learning', which includes educational events, personal experiences, identity issues, beliefs, fears, desires, preferences, as well as personal and institutional relationships. Paiva claims that the learner's view of the way languages are learned may provide insights into Second Language Acquisition. The author argues that a research that focus on the learner's experiences helps researchers to switch from the objectivist to the experientialist paradigm, also helping to understand how languages are learned from a learner's perspective, starting from an emic point of view. Paiva (2010) suggests that foreign language learners' narratives give voice to the learners, who express their experience, memories and emotions by delivering their own explanations on how they learn or on how they have learned a foreign language. The results of this study present some more evidence, which support this view.

Ferreira (2014) carried out a study where university students had been asked to conceptualize their experience of learning German as a Foreign Language. The discursive metonymy LEARNING IS A CONTAINER appeared in expressions such as "to speak German is to be inside, not to know German is to be outside", "[...] it is to walk into a labyrinth and not being able to find the way out", "[...] sometimes to know German is as 
if you were on a desert island". Participants have also expressed their experience with German as a Foreign Language as something negative using discursive metaphors like "...it was a wrong decision on my part". In order to express those difficulties, one student talked about "crossing a river without being able to swim". Students have also employed conceptual metaphors like LEARNING IS DISCOVERY and LEARNING IS TO GO THROUGH HURDLES to talk about their experience with learning German. Students taking part in the study mentioned that being able to read and translate to/from German are also reasons for learning the language.

\section{Research questions}

The investigation focus on discourse data produced by focus groups' participants as they engage in conversations about their foreign language learning experience in Brazil and abroad. ${ }^{18}$ It is of particular interest to analyze attitudes, beliefs and values and how figurative language such as metaphors and metonymies emerge in their speech as participants interact verbally around the topic of learning German for Academic Purposes and their motivation to participate in the study abroad programs.

Which metaphors and other figurative language appear in learners' speech when they try to explain how they learn German for Academic Purposes?

How are those learning practices explained through the metaphors and other figurative language that are at play?

Other related questions: ${ }^{19}$

- How is it to learn German?

- Why do participants learn German?

- What difference does an exchange program make in this process?

\footnotetext{
${ }^{18}$ At the time, only students in the B1 group had already studied at a German University. Their goal in the UFMG German courses was to improve language proficiency to be able to go back to Germany to study.

${ }^{19}$ Adapted from SILVA (2013). 


\section{Method}

The data were collected from a structured focus group discussion with three groups of learners of German for Academic Purposes (A1, A2, and B1 levels) ${ }^{20}$ at the Federal University of Minas Gerais. Students were requested to answer thirteen questions related to their experience with learning a foreign language ${ }^{21}$ in general and particularly to elaborate on their experience with learning German for Academic Purposes at University. ${ }^{22}$

It has been tried to elicit which metaphors students employ when attempting to explain their learning practices, and it has been tried to analyze which learning models underlie such metaphors. Since learning cannot be directly observed, an attempt has been made to describe what someone does when learning a foreign language, i.e. the tools the learners use. Learners were encouraged to recall their previous learning practices and to relate it to their current experience and motivations for learning GAP.

\subsection{Participants and procedures}

Six voluntary participants, aged between 17 and 44 years-old, three men and three women, undergraduate students at the Federal University in Belo Horizonte (UFMG), Brazil, took part in the study in May 2014. ${ }^{23}$ In order to promote the discourse interaction during the focus group discussion, one member of the research team acted as moderator in the discussion. The session (5,641 words) lasted about 40 minutes. A total of 123 metaphors were identified and students employed 21.82 metaphors per 1,000 words. Focus group discussions usually last between 1-2 hours (DöRNYEI 2007). However, the data of this study was collected just before finals started, students were already writing exams and this

\footnotetext{
${ }^{20}$ In fact, we collected data with A1, A2 and B1 levels but only one A1 level group has been analyzed in the present study.

${ }^{21}$ Based on Silva (2013).

${ }^{22}$ I would like to thank the AFA teachers, including the German Teaching Assistant (GTA-Capes/ DAAD), of the German for Specific Purposes program (Alemão para Fins Acadêmicos/ AFA) at the Faculty of Letters (FALE) at the Federal University of Minas Gerais (UFMG), who allowed me to collect data during their classes in 2014. I also would like to thank Catarina Flister (PROBIC-FAPEMIG), who assisted me with the transcription of the data and with the review of the article.

${ }^{23}$ The project has been previously approved by the Federal University of Minas Gerais research ethics committee.
} 
fact led some students to be late for the session or to skip class due to other exams. That fact had as a consequence a shortening in the duration of the data collection sessions.

Each session was video recorded ${ }^{24}$ although only the audio part has been used in the analysis presented here. The transcription was double checked by the research team in order to guarantee accuracy. Pseudonyms were adopted to protect the participants' identities. Since students are not proficient in German yet, the data collection was conducted in their mother tongue, which is Brazilian Portuguese.

The transcribed data were subjected to metaphor-led discourse analysis (CAMERON ET AL. 2009). The data was coded for metaphors, metonymies, discursive topics, and image schemas. Individual metaphors and metonymies were collected together into groups to find systematic patterns and framing metaphors were identified. The steps followed in the study are explained below.

A modified version of the Metaphor Identification Vehicle (MIV) method, as defined by Cameron (2003), has been adopted. Metaphor vehicles were identified and coded. After that, metaphor vehicles were grouped into families. For instance, words or expressions related to foreign language learning were grouped together, etc. Linking categorizations to metaphor vehicles and discourse topics allowed the identification and characterization of the systematic metaphors and metonymies.

As Cameron et al. (2010: 91) posit, 'Within the discourse dynamics framework, a systematic metaphor is a collecting together of related linguistic metaphors that evolve and are adapted as the discourse proceeds'. Hence, a top-down as well as a bottom-up analysis was adopted in proposing a number of systematic metaphors and metonymies in the discourse of the participants and then linking them to themes across the discourse event, in order to identify the trajectories of possible systematic metaphors. According to Cameron's framework, we adopted Intonation Units in the transcription. Intonation Units (IUs) are stretches of speech that include ideas of people, objects, events, and states. IUs are seen as playing both cognitive and interactive roles in spoken discourse (STELMA; CAMERON 2007: 367).

\footnotetext{
${ }^{24}$ The recordings were transcribed by two members of the research team using the software for qualitative analysis atlas.ti.
} 
When reading the transcriptions of the focus group discussion, some metaphors and metonymies (i.e. their respective vehicles) were recurrent across the discourse produced by the participants under the discourse topic 'learning German for Academic Purposes' and such metaphors seemed to describe their beliefs and ideas about the roles 'German as a foreign language' has played in building their attitudes towards foreign language learning as it is shown below.

\section{Metaphor use in learners' discourse about learning German for Academic Purposes}

A discourse event like a focus group discussion emerges from the interaction among its participants. The emergent metaphorical language delivers ways of talking-and-thinking (CAMERON 2003), which end up stabilizing in discourse due to the salience of metaphorical language.

In the following extract a focus group interaction is analyzed, and it shows clearly how the metaphor dynamics evolves and how participants co-construct an idea through the use of subsequent systematic metaphors and metonymies in the flow of talk. As Cameron asserts "our objects of concern are not isolated linguistic metaphors but strings of connected metaphors and the patterns of meaning that they produce or reflect" (2010: 6). Therefore, the goal here is to use metaphor as a research tool in order to uncover people's thoughts, emotions and beliefs, as it is shown in the extract below:

Question 1: How is learning German for you?

\section{Extract 1}

71. Marta: ...(0.3) Ah um desafio,

72. ..porque é mui -

73. pelo menos pra mim,

74. é,

75. a pronúncia é muito complicada,

76. eu ainda $\mathrm{n}-$

77. é uma coisa que eu tô, 
78. eu tô tendo que..trabalhar bastante,

79. mais que o vocabulário,

80. assim,

81. saber ler sabe?

82. acho que saber falar é mais difícil que saber ler,

83. ..e $=$,

84. só que é motivador,

85. porque eu acho muito interessante cê aprender coisas diferentes,

86. ..e o alemã $=0$,

87. por ser bem diferente do -

88. português,

89. pelo menos eu acho um pouquinho,

90. me chama bem atenção,

91. ..então é uma coisa que é,

92. eu gosto,

93. ...mais que o inglês.

94. Joaquim: eu acho interessante porque,

95. assim,

96. a gente,

97. é,

98. há muitos anos,

99. três anos que eu estudo inglês,

100. e eu consegui associar bastante,

101. as duas línguas,

102. acaba tendo uma $=$

103. não sei se,

104. é,

105. uma proximidade uma com a outra,

106. apesar de ter uma dificuldade de pronúncia,

107. é totalmente,

108. não totalmente, 
109. mas parcialmente diferente,

110. então achei interessante.

111. Paula: $\mathrm{O}$ meu contato com o alemão,

112. foi lá na Letras mesmo,

113. com o Raul,

114. $\mathrm{e}=$,

115. ..simplesmente eu entrei em pânico,

116. porque ele falava,

117. 200\% só alemão,

118. só alemão,

119. e,

120. $\mathrm{t}$ - fragen?

121. eu tenho,

122. eu tô no básico,

123. porque,

124. pra mim foi um,

125. ..um susto muito gra=nde,

126. assim,

127. não entendia nada,

128. tive que estudar bastante em casa,

129. pra conseguir pegar,

130. no final do curso já deu,

131. agora,

132. hoje eu falo que=,

133. ..meus filhos fazem inglês,

134. eu falo inglês,

135. ..e quem quer aprender uma língua,

136. manda aprender primeiro o alemão,

137. eu tô achando mais fácil do que o inglês.

138. mas é claro que tem que estudar,

139. mas, 
140. ..é=,

141. tem essa barreira a gente,

142. tem uma cultura voltada $\mathrm{s}-$

143. né?

144. só pro inglês,

145. a gente só escuta música em inglês,

146. só vê filme americano,

147. se a gente tivesse um pouco do alemão eu acho que a gente ia tá,

148. ..ia tá,

149. ia tá [entrando] mais na cabeça.

150. Marta: [se expressar].

151. Paula: Eu acho que,

152. ..eu,

153. eu consigo ver o alemão mais perto do português do que o inglês.

[Marta: ...(0,3) Hm a challenge,/ ..because it is ver - / at least for me,/it is,/ the pronunciation is very complicated,/ I still don - / this is something that I,/ I have to..work hard on,/ more than vocabulary,/ like,/ to learn how to read you know?/ I guess knowing how to speak is more difficult than knowing how to read,/ ..a=nd,/ it is motivating,/ because I find it very interesting to learn different things,/ ..and Germa=n,/ because it is very different from - / Portuguese,/ at least I think it is a bit so,/It calls much of my attention,/ ..then it is something,/ I like,/ ..more than English./ Joaquim: I find it interesting because,/like,/ we,/yes,/it has been years,/ three years learning English,/and I get to relate a lot,/both languages,/ it ends up having some=,/ I am not sure if,/ it is,/ a proximity of one with the other,/ although there is a difficulty in pronunciation,/ it is totally,/ not totally,/ but apparently different/ so I found it interesting./ Paula: my contact with German,/ it was at the Faculty of Letters,/ with Tony,/ a=nd,/ ..I simply started to panic,/ because he talked,/ 200\% only German,/ only German,/ and,/ t-fragen?/ I do,/ I am in the basics course,/ because,/ to me it was,/ ..I was sca=red,/ so,/ I could not understand anything,/ I had to learn a lot at home,/ in order to grasp it,/ by the end of the course it was OK,/ now,/ today I say tha=t,/.. my children learn English,/ I speak English,/ ..and for those who want to learn a foreign language,/ go and learn German first,/ I think it is easier than English./ but of course you've 
got to study,/ but,/ ..it $\mathrm{i}=\mathrm{s}$, there is this hurdle we,/ we have a culture turned $\mathrm{s}-$, / isn't it?/ only to English,/ we listen to music only in English,/ we only watch American movies,/ if we had a bit more of German it would,/ ..it would,/ it would be [getting] more into our heads./ Marta: [to express itself]./ Paula: I guess,/ ..I,/ I get to see German nearer to Portuguese than English.]

The data presented above are from an A1 group, ${ }^{25}$ where learners with different background (there were Engineering students, as well a student from Fashion Design) talk about their experience of learning German and their expectations regarding the exchange programs available at the university. The reason for grouping this first set of answers together was the fact that the students' answers seemed to be sort of interconnected around the same discursive topic, which was the 'motivation to learn German'. Students used many cognitive metaphors, which reflect the acquisition metaphor, such as the mind as a CONTAINER that needs to be filled (EDWARDS ET AL. 2004). Those acquisition metaphors point to a more individualized, self-interested view of learning. Another example of an acquisition metaphor is when Marta described the learning of pronunciation as something she has to 'work hard' on, maybe motivated by the underlying primary metaphor DIFFICULTIES ARE WEIGHTS (GRADY 1997). Paula describes meaning as an object, ${ }^{26}$ which can be 'grasped'. She defines the Anglo-American culture as a 'hurdle', which hinders the German culture and language of occupying more space and finding some recognition in Brazil. 'Hurdle' is a clear reference to the JOURNEY metaphor, in which difficulties are impediments to travelling. The CONTAINER image schema is referred to many times along the students focus group interaction, as it appears in Paula's speech above, where she mentions the head as a CONTAINER for knowledge. PROXIMITY metaphors are used by Martha first, and then employed again by Paula in order to compare German with other languages she knows, in both cases they are talking about English and Portuguese. Paula also expresses her feelings about the German language, referring to the moment she first heard it in a lecture as 'I started to panic' (1.115) and got 'scared' (1. 125), that is using emotion and feelings' metaphors.

\footnotetext{
${ }^{25}$ According to the Common European Frame of Reference.

${ }^{26}$ IDEAS ARE OBJECTS cf. LAKOFF AND JOHNSON (1980).
} 
There are basically two metaphors at play in the extract (1) above, that is the metaphor of the community of practice and the acquisition metaphor of learning. Those two metaphors reveal the conceptions of learning of the participants in this study. The metaphor of the community of practice views learning as an activity, hence when learners talk about how much they are doing to improve their German skills, they are talking in terms of that metaphor. Participation metaphors indicate the social dimension of learning. On the other hand, when learners talk about their head as a container to be filled, they are using the acquisition metaphor, which goes back to a more individualized, self-interested view of learning. Paula (line 153) employs UNDERSTANDING IS SEEING (SwEETSER 1990), that is another cognitive metaphor, in order to express how she believes that Portuguese is closely related to German.

Edward et al. (2004) claim that metaphors of movement and journey introduce a certain spatial relationship to learning, depending upon the emphasis placed on the point of departure and arrival, and the moving experience itself. This claim is based on Lakoff and Johnson's (1980) argument that most of our fundamental concepts are organized in terms of one or more spatial metaphors, and that spatiality is so essential that it is difficult to find any alternative metaphor that could structure the concept, probably due to its abstract characteristics. Hence, spatial metaphors which conceptualized the head as a CONTAINER were recurrent in the data, as Paula's speech below revealed: 'we have a culture turned s ,/isn't it?/only to English,/we listen to music only in English,/ we only watch American movies,/ if we had a bit more of German it would,/ ..it would,/ it would be [getting] more into our heads'.

Also metonymies using spatial prepositions with the idea of containment (for instance, in Graduation, at University, in the language program) were recurrent in the data analysed. It seems that the interactions between those college students, who share a common ground and a mutual identity as foreign language learners, are both interconnected by those strings of systematic metaphors and metonymies, but also intertwined by the cognitive metaphors/ metonymies and image schemas shared by the participants in the discussion.

In extract (1), Paula (line 141) mentions the 'hurdle' which the ubiquity of the American culture represents, keeping the other cultures like the German culture out of 
reach. In the next extract (2), Joaquim (1.183) employs the 'hurdle' linguistic metaphor previously used by Paula to introduce an example of difficulty found when learning German. 'Hurdle' emerges as a systematic metaphor used in the flow of talk, conceptually motivated by the EDUCATION IS A JOURNEY conceptual metaphor. The whole discourse event goes around the topic stated, which is 'German' and its difficulties, described by Marta as a 'challenge'. Joaquim employs vehicle development, further elaborating on the 'challenge' of learning German introducing a concrete example, which is German 'pronunciation' (1.75). In the same discourse event, framed by the discourse topic "how is it to learn German", other difficulties were mentioned by the participants of the focus group discussion as 'vocabulary' (1. 79) and 'phonetics' (1. 187). This type of talk, which links the concepts to the experiences of the students, is called 'Vehicle contextualization' (CAMERON 2003). Also as part of vehicle development, more specifically vehicle explication, Paula closes the discourse sequence with a comparison between languages, which had been previously introduced by Joaquim (1. 105). Both participants use the metaphorical vehicle 'proximity' to talk about how similar both English and German (Joaquim) and Portuguese and German (Paula) are.

Martha and Benício support Paula and Joaquim's statements on the difficulties of learning German as a foreign language in Brazil with other arguments using the systematic 'hurdle' metaphor ('barreira' in BP), mentioning other examples of difficulties, such as the speed of speech when Germans sing (Martha has been trying to pick up some German pronunciation listening to German songs). Hudson (1984) talks about 'progression' on careers. Initially he focused on progress up ladders or races across hurdles, both familiar metaphors of movement. The whole movement in the interaction (Extracts 1,2) goes from the topic German language and the 'hurdle' metaphor to the different topics, i.e. pronunciation, phonetics, vocabulary, grammar, and learning materials introduced by the students.

Joaquim, Marta, and Benício add different features to each vehicle, hence the phonetics is difficult, the songs are sung too fast, and the learning materials are not reliable. All these are factors that sum up to the difficulties of learning German, revealing how the development of the vehicle concepts is co-constructed by the members of the focus group in a dynamic non-linear way. In the sequence of talk, Ana (Extract 2) summarizes the 
difficulties and concludes using the linguistic metaphor "it is a search on your own" ('procura por conta própria' in Brazilian Portuguese). Following the same line of thought, Benício mentions the lack of reliable materials for learning German. Another issue mentioned during the focus group discussions was the lack of materials to learn German for Specific Purposes, since all participants in the focus group have a specific goal for learning German, which is to study in Germany in their field of expertise. Martha pointed out this issue in the sequence below.

\section{Extract 2}

182. Joaquim: É,

183. pra mim uma grande barreira é a questão fonética,

184. né?

185. totalmente diferente,

186. <xx> português.

187. Marta: e eles falam rápido,

188. pelo menos nas músicas

189. eles falam rápido.

190. Benício: material também,

191. é difícil você achar um material confiável..

192. Joaquim: Justamente todos os materiais são,

193. ..na mão inglesa,

194. né?

195. Benício: É bom que,

196. a Ticiana posta tudo no..Dropbox,

197. ..aí a gente -

198. facilita pra nós,

199. mas ao mesmo tempo não é fácil,

200. você for estudar,

201. sozinho,

202. con-

203. pegar o material confiável é muito complicado.

204. Marta: e na internet cê só acha material pra pessoas que vão viajar, 
205. então não tem uma gramática,

206. é só aquela -

207. algumas palavras..

208. básicas,

209. e chaves pra você chegar e falar que você está com fome,

210. Benício: Isso.

211. Marta: $\mathrm{Que}=$ você es -

212. pedir informação,

213. entendeu?

214. então,

215. Nelson: Realmente,

216. de material assim,

217. você encontra mais,

218. mais frase $=$,

219. frase feita pra,

220. ..frase clichê,

221. Marta: e cê não sabe porque que é [assim],

222. Nelson: [do que] gramática mesmo.

223. Marta: aham,

224. ..então o -

225. é o dropbox ajuda bastante.

226. Ana: é e essa questão,

227. acho que eu sinto mais essa questão da,

228. da,

229. da gente nunca ter tido um contato até então,

230. tá sendo uma procura por conta própria,

231. né,

232. cê,

233. ..é= a gente lida muito com o inglês e o espanhol,

234. e acaba ali,

235. então é tudo muito novo, 
236. ..muito,

237. ..cê pega,

238. cê,

239. ..vê um pouquinho do=,

240. inglês assim algumas -

241. alguns sons,

242. mas ao mesmo tempo,

243. quando cê... lê a palavra,

244. cê fala,

245. poxa quê que é isso?

246. tem uma-

247. um susto inicial assim com a língua.

[Joaquim: It's,/ for me a great hurdle is the phonetic issue,/ right?/ totally different,/ $\langle\mathrm{XX}\rangle$ Portuguese./ Marta: and they speak fast,/ at least in the songs/ they speak fast./ Benício: resources too,/ it's difficult to find reliable resources,/ Joaquim: it's exactly that every resource is, /.in the English hand,/ right?/ Benício: It's good that,/ Ticiana posts everything on..Dropbox./ ..then we - / it makes it easier for us,/ but at the same time it's not easy./ you study by yourself,/ ge - / finding reliable material is very tricky./ Marta: and on the internet you only find material for people who are travelling,/ so there's no grammar,/ it's just that - I some words/ basic words, / keys for you to get there and say that you are hungry,/ Benício: Yes./ Marta: Tha=t you ar - / ask for information,/ you know?/ so,/ Nelson: It's true,/ material like this,/ you find more sentence $=\mathrm{s}$,/ sentences made to - / ..cliché sentences./ Marta: and you don't know [why it is so]./ Nelson: [than grammar]./ Marta: aham./ ..so I think - / Dropbox helps a lot./ Ana: yes and this issue,/ I think I feel more the issue of,/ of,/ of we having never been in touch with it so far, / it's been a search by ourselves,/ right,/ you,/..and we deal a lot with English and Spanish,/ and that's it./so it's all very new,/ ..very,/ ..you take,/ you,/ you see a little o=f,/ English like some - / some sounds,/ but at the same time,/ when you.. read the word,/ you say,/ wow what is this?/ there's a - / an initial scare like with the language.]

In the two extracts above the participants in the focus group discussion go on talking about the 'hurdles' for learning German, as the lack of good learning materials, 
although they mentioned the teacher really motivates them with extra materials, which she makes available online. It is striking how Marta's speech reveals a belief on a traditional grammar based method since she complains the learning materials available focus only on communication. Marta uses the metaphor keys (line 209) referring to basic words that she learns to have access to basic vocabulary. 'Key' is a metaphorical vehicle for access (GRADY 1987). This vehicle appears many times along the discourse event. For instance, Joaquim employs this vehicle, which ends up emerging as a systematic metaphor in the interaction, to talk about "the key to understanding" (line 585).

The sequence above reveals that the learners see the teacher (Ticiana) as a facilitator that provides them with materials and support, turning their learning experience into an autonomous process. Student-centred learning, as an alternative to teacher-centred learning, has been spread among progressive educators for many years. Setting students in the center of the learning process should respond to their intellectual, practical, and emotional needs, enabling them to learn more successfully. According to this approach, students play an active role in their learning process, moving and interacting with the learning objects, that is 'constructing' knowledge. This approach draws on the embodied and spatial metaphor since students interact also physically with the knowledge as they move around.

In the first extract Paula reports how she felt 'scared' ('susto' in Brazilian Portuguese) when she attended a lecture in German at the Faculty of Letters due to the fact that the lecturer would only talk in German. Ana uses vehicle repetition (CAMERON, 2008: 57), employing the metaphor 'scared' to refer the difficulties with English spelling.

The extract above also shows how much curiosity motivates those learners on their journey in search of proficiency in the foreign language, as well as the role of autonomy in this process (Ana, line 231), since those students seem to be always looking for new materials and tools for improving their proficiency and for apps they can access from their mobile phones. In fact, those students are actively looking to improve their proficiency in German in an autonomous way. Students interact about their experience when they attend classes and end up becoming part of a community of practice. Learning in such a context is located in the daily practice of the group, which shares a common goal (studying in Germany) and an identity (learners of German). As Edwards et al. (2004: 39) pointed out, 
"the spatial ordering of a community of practice to which one belongs or could belong evokes powerful feelings of identification".

With the next question, there is an attempt to address the different motivations of the students for learning German.

Question 2: Why do you learn German?

In the next sequence, Paula chose the BUILDING metaphor (LAWTON 1984) to describe the metaphoric grounds her knowledge of the German language is based on. She employs the BUILDING metaphor talking about the 'structure' of the language, another metaphor related to the same conceptual domain. Paula talks about the German language resorting to metaphors of sound and rhythm aiming at describing it in terms of its sonority.

\section{Extract 3}

523. Paula: eu acho que lá na Letras,

524. me deu uma base melhor do que aqui,

525. assim,

526. eu não sei se aqui também,

527. já era pra ter vindo,

528. mas,

529. também,

530. a dificuldade lá foi maior,

531. né,

532. é =,

533. ...então eu,

534. eu ti -

535. eu traduzia tudo,

536. e decorava tudo,

537. absolutamente tudo,

538. e a partir daí cê vai sabendo como que e=h,

539. ..como que se estrutura,

540. e mesmo assim,

541. pegava pra ler e botava o áudio, 
542. ..e num entendia nada,

543. mesmo lendo,

544. não entendia nada,

545. e ficava,

546. ficava,

547. mas depois de um tempo -

548. eu acho assim que depois de,

549. ...sei lá,

550. ...né,

551. desses seis meses que eu passei,

552. eu falo que eu comecei a entender o alemão assim,

553. eu acho que a gente tem que,

554. ..e $=\mathrm{h}$,

555. ..perceber a sonoridade,

556. cada língua tem uma sonoridade,

557. então na hora que ocê capta essa sonoridade,

558. o negócio fica mais fácil,

559. você entender,

560. ..então eu falo que o alemão agora eu já tô me -

561. eu estava,

562. né?

563. porque,

564. não tá no mesmo ritmo,

565. né,

566. mas assim,

567. pelo menos,

568. eu j-

569. eu já consigo ver a sonoridade pra começar a entender o quê que tá se falando,

570. dá pra-

571. às vezes quando se fala alguma coisa, 
572. dá procê entender uma palavra ou outra jogada,

573. mas não consigo formar frase escutando,

574. ..não consigo,

575. são palavras jogadas,

576. assim.

577. Joaquim: Agora falar que nessa questão,

578. tipo assim,

579. não é entender todo o texto,

580. e sim,

581. ..pelo menos,

582. ..o que o texto tem como objetivo principal,

583. né?

584. ...fundamental,

585. algumas palavras ali já te dão uma chave pra..entender.

586. Nelson: [É $n-$ ]

587. Marta: [Foi assim] que eu fui tentar no inglês,

588. porque,

589. pra eu estudar vestibular,

590. é até uma vergonha eu falar isso,

591. mas eu pro -

592. ..té um,

593. um ano e meio atrás,

594. eu não sabia nada de inglês,

595. porque eu era,

596. sempre fui uma criança muito arteira,

597. s- peguei pra estudar mesmo,

598. $\mathrm{e}=\mathrm{h}$,

599. no,

600. no ensino médio,

601. só que eu estudava matemática e física,

602. daí preu estudar.. mesmo, 
603. eu tive que pes -

604. pegar no último ano,

605. então daí eu semp -

606. pra-

607. pros textos,

608. eu só estudava as palavras-chaves,

609. pra mim conseguir fazer a prova,

610. então eu fiquei um ano estudando nesse estilo,

611. e eu c-

612. meio que carreguei isso pro alemão,

613. ..estudar as palavras-chave pra entender o texto.

614. Nelson: é,

615. realmente a questão de tentar traduzir a frase toda,

616. $\mathrm{e}=\mathrm{h}$,

617. num,

618. num,

619. num funciona muito bem,

620. né?

621. no final das con -

622. das con-

623. no final das contas,

624. $\mathrm{o}=$ contexto te fala muito sobre,

625. ..sobre o significado daquilo,

626. ...̀̀s vezes você pega uma,

627. ..algumas palavras-chaves,

628. no meio da frase,

629. e o contexto te fala todo o resto.

[Paula: I think there at the Faculty of Letters,/ I got a better foundation than here,/ so,/ I don't know if here too,/ was supposed to have already come,/ but,/ also,/ the difficulty there was greater,/ right,/ ye=s,/ ..so I,/ I ha - / I translated everything,/ and memorized everything,/ absolutely everything,/ and from then on you start knowing what's like,/ ..how 
it structures,/ and even so I read and listened to the audio,/ ..and I understood nothing,/ even reading,/ I understood nothing,/ and tried,/ tried,/ but after a while - / I think that after,/ ..I don't know,/ ..right,/ in the six months I went through,/ I say that I started to understand German,/ I think we have to,/ ..eh,/ ..perceive the sounds,/ each language has its sound pattern,/ so when you capture those sounds,/ it gets easier,/ you understanding,/ ..so I say that German now I've already gotten us - / I was,/ right,/ because,/ it's not on the same pace,/ right,/ but like,/ at least,/ I c - / I can see the sound patterns to start understanding what is being said,/ I can - / sometimes when something is said,/ you can understand a word that is thrown here or there,/ but I can't form a sentence listening,/ ..I can't,/ they're thrown words,/like that. /Joaquim: Now talking about this issue,/ like,/ it's not understanding the whole text,/ but really,/ ..at least,/ ..what the text has as a main purpose,/ right?/ ..fundamental,/ some words there give you a key to..understand./ Nelson: [It's in - ]/ Marta: [That was] how I tried English,/ because for me to study for vestibular,/ I feel ashamed to say it,/ but I - / ..until one,/ one-and-a-half-year ago,/ I knew nothing about English,/ because I was,/ I've always been a very naughty kid,/ on- started to really study,/ $\mathrm{hu}=\mathrm{m}, /$ in,/ in high school,/ but I only studied math and physics,/ so for me to study...really,/ I had to pes - / get on in my senior year,/ so then I alwa - / to - / for texts,/ I only studied the keywords,/ so that I could do the test,/ so I spent one year studying in this style,/ and I c - / kind of carried this to German,/ ..studying the keywords to understand the text./ Nelson: yes,/ in fact the issue of translating the whole sentece,/ hu=m,/ doesn't,/ doesn't,/ doesn't work very well,/ right?/ at the end of the $-/$ of the $-/$ at the end of the deal,/ the $=$ context tells you a lot more about,/ ..about the meaning of that,/..sometimes you take a,/..a few keywords,/ in the middle of the sentence,/ and the context tells you the rest.]

In this discourse event, participants describe their learning strategies, for instance Joaquim uses again the conventional metaphor key on a clear reference to keywords used to get the gist of a text when reading in a foreign language. Key is a known metaphor for access. Students also talk about the German language in terms of OBJECTS they can pick up (line 626) and of KNOWLEDGE as an object they can carry (line 612).

Participants talk about the importance they attribute to context in comprehension, and how their learning strategies have evolved throughout time. Nelson reveals a conception of learning as translation, which relies on a method used in the Fifties called the 
Grammar and Translation. He acknowledges that that method does not work very well and that he tries to grasp the meaning based on the context.

Question 3: What difference does the possibility of studying abroad make in your learning process?

Extract 4

993. Ana: da língua?

994. nossa,

995. acho que toda, (risos)

996. ...eu,

997. eu sô,

998. $\mathrm{eu}=$

999. ..aprendo muito mais fácil

1000. quando eu tô vivendo naquele meio.

1001. então acho que assim,

1002. a evolução é=,

1003. ..vai ser muito diferente,

1004. se a gente tiver num,

1005. num intercâmbio,

1006. ..que -

1007. porque $=$,

1008. igual cê tinha comentado,

1009. ..é uma,

1010. língua é uma coisa que é importante se ocê que=r,

1011. aprender ela mesmo,

1012. e quer aprender de forma eficiente,

1013. é importante cê vê um pouquinho todo dia,

1014. ..e no intercâmbio que cê tá imerso naquele meio,

1015. respirando a língua que cê,

1016. vai ter que aprender,

1017. ..acho que sua evolução,

1018. ..é muito maior. 
1019. Nelson: eu acho que também,

1020. no processo de intercâmbio,

1021. ajuda no=,

1022. no seguinte aspecto,

1023. ..quando você sabe uma determinada língua mas nunca aplicou ela nu=m,

1024. numa situação,

1025. ...numa situação real,

1026. cê fala inglês,

1027. mas nunca,

1028. ..conversou com alguém,

1029. ..alguém nativo,

1030. ou então nunca,

1031. ..foi pro Estados Unidos,

1032. alguma coisa assim,

1033. é=,

1034. cê tem um pouco de medo de,

1035. ..a hora que chegar o momento de,

1036. ..utilizar aquele seu conhecimento,

1037. não conseguir,

1038. $\mathrm{e}=\mathrm{h}$,

1039. aplicar ele,

1040. então eu acho que,

1041. o processo de intercâmbio ajuda nisso,

1042. quebra esse,

1043. ...esse medo.

[Ana: of the language?/ man,/ I think every, (laughter)/.. I,/ I just,/ I=,/.. learn a lot easier,/ when I'm living in that environment./ so I guess like,/ the evolution $\mathrm{i}=\mathrm{s}$, / ..will be very different,/ if we are in, in a,/ an exchange experience,/..that - / becau=se,/ like you had mentioned,/..it's a,/ language is something that's important if you wa $=$ nt,/ to really learn it,/ and want to learn it efficiently,/ it's important that you see a little every day,/ ..and abroad you are immersed in that environment,/ breathing the language you,/ you'll have to 
learn,/ ..I think your evolution,/ ...is much greater./ Nelson: I also think that,/ in the process of studying abroad,/ helps $\mathrm{i}=\mathrm{n}, /$ in the following aspect,/ ..when you know a language but never applied it $\mathrm{i}=\mathrm{n}, /$ in a situation,/ ... in a real situation,/ you speak English,/ but never,/ ..talked to someone,/ ..someone native,/ or has never,/ ..been to the United States,/something like that,/ i=t's,/ you're a little scared of,/ ..when the time comes to,/ ..use your knowledge,/ you can't,/ hum,/ apply it,/ so I think that the,/ process of studying abroad helps in this,/ breaks this,/ ..this fear.]

In the extract above, students employ again metaphors related to 'senses' to describe their learning experience. In the data, it was possible to identify the following metaphors referring to different senses related to the human perception, such as VISION (verb 'see', used in the metaphor UNDERSTANDING IS SEEING) (SWEETSER 1990), HEARING (sonority, rhythm of the language), and TOUCH (grasp, contact). There is also some explicit reference to basic bodily functions such as 'breath', employed in the metaphorical expression 'you are able to breathe the language', and also to basic bodily emotions as the 'fear' of not being capable of speaking the language when arriving in Germany. In the first and second extract, Paula and Ana talked about emotions like being 'scared', experiencing 'panic' (Paula in lines 115, 125), then employed by Ana again in another sequence of talk (1. 247) when they first heard the language, so feelings related to students' expectations about learning German appear along the interaction, revealing how language is shaped by embodiment.

\section{Final remarks}

Those findings are strong evidence that the discursive data analysed in the present study is motivated by embodiment (JOHNSON 1987; GIBBS 2006). Embodied meaning is interconnected with emotions when students try to describe their feelings and motivations for learning German for Academic Purposes. The fact that those linguistic, systematic metaphors emerge along the discourse event together with other cognitive metaphors, both motivated by the same discourse topic, support Gibbs and Coulson's claim that "we need to seek convergences between different levels of analysis" (2012: 343), for instance from the conceptual to the linguistic level, and try to reveal the dynamic couplings which link them.

Pandaemonium, São Paulo, v. 19, n. 28, set.-out. 2016, p. 124-152 


\section{References}

Berber SARDinha, Tony. Metáfora. São Paulo: Parábola, 2007.

CAMERon, Lynne. Metaphor in Educational Discourse. London: Continuum, 2003.

In: Zannotto, Mara; CAVAlCANTI, Marilda (Ed.). Confronting Metaphor in Use. Amsterdam: John Benjamins, 2008.

CAMERon, Lynne; MASlen, Robert; TodD, Zazie; MAUle, John; Stratton, Paul; STANLey, Neil. The Discourse Dynamics Approach to metaphor and Metaphor-Led Discourse Analysis. Metaphor and Symbol, v. 24, n. 2, p. 63-89, 2009.

CAMERON, Lynne; LOW, Graham; MASLEN, Robert. Finding systematicity in metaphor use. In: CAMERON, Lynne; MASLEN, Robert (Ed.). Metaphor analysis: Research practice in applied linguistics, social sciences, and the humanities. London: Equinox, 2010. p. 116-146.

CORTAZZI, Martin; JIN, Lixian. Bridges to Learning, metaphors of teaching, learning and language. In: CAMERON, Lyne; LOW, Graham (Ed.). Researching and Applying Metaphor. Cambridge (UK): Cambridge University Press, 1999. p. 149-176.

DÖRNYEI, Zoltan. Research Methods in Applied Linguistics. New York: OUP, 2007.

EDWARDS, Richard; NICOLL, Katherine; SOLOMON, Nicky; UsHER, Robin. Rhetoric and Educational Discourse: Persuasive texts. London: Routledge Falmer, 2004.

FALCK, Marlene Johansson. Metaphor variation across L1 and L2 speakers of English: Do differences at the level of linguistic metaphor matter? In: MACARTHUR, Fiona; ONCINSMARTINEZ, José Luis; SÁnchEZ-GARCíA, Manuel; PIQUER-PIRIZ, Ana María (Ed.). Metaphor in Use: Context, culture, and communication. Amsterdam; Philadelphia: John Benjamins, 2012. p. 109-134.

FERREIRA, Luciane Corrêa. A compreensão da metáfora em língua estrangeira. 2007. 219 f. Tese (Doutorado em Letras) - Instituto de Letras, Universidade Federal do Rio Grande do Sul, Porto Alegre, 2007.

Lernmetaphern Eine Studie über die Motivation für das DaF-Lernen. In: DEUTSCHER AKADEMISCHER AUSTAUSCHDIENST (Hrsg.). Germanistik in Brasilien: Herausforderungen, Vermittlungswege, Übersetzungen. Göttingen: Wallstein, 2014. p. 74-76.

GRADY, Joseph. Foundations of meaning: Primary metaphors and primary scenes. PhD Dissertation (Doctorate in Philosophy in Linguistics) - Graduate Division, University of California, Berkeley, 1997.

GIBBS, Raymond. Embodiment and cognitive science. Cambridge (UK): Cambridge University Press, 2006.

. The social nature of embodied cognition: A view from the world of metaphor. Intellectica, n. 56, p. 81-98, 2012.

GIBBS, Raymond; COLSTON, Herbert. Interpreting figurative meaning. New York: Cambridge University Press, 2012.

GoldEN, Anne. Metaphorical expressions in L2 production. The importance of the text topic in corpus research. In: MACARTHUR, Fiona; ONCINS-MARTÍNEZ, José Luis; SÁNCHEZGARCÍA, Manuel; PIQUER-PÍRIZ, Ana María (Ed.). Metaphor in use: Context, culture, and communication. Philadelphia: John Benjamins, 2012. p. 135-148.

Pandaemonium, São Paulo, v. 19, n. 28, set.-out. 2016, p. 124-152 
GOMES JUNIOR, Ronaldo Correa. Metáforas do eu: as identidades metaforizadas de aprendizes universitários de inglês em Hong Kong e no Brasil. 2015. 180 f. Tese (Doutorado em Linguística Aplicada) - Faculdade de Letras, Universidade Federal de Minas Gerais, Belo Horizonte, 2015.

HEITZ, Monika. Herausforderung "Deutsch für den akademischen Gebrauch". Überlegungen zum steigenden Bedarf an studienvorbereitungen Kursen für brasilianische Austauschstudenten vor Ort in Brasilien. In: DEUTSCHER AKADEMISCHER AUSTAUSCHDIENST (Hrsg.). Germanistik in Brasilien: Herausforderungen, Vermittlungswege, Übersetzungen. Göttingen: Wallstein, 2014. p. 112-115.

Hudson, Liam. The Role of Metaphor in Psychological Research. In: TAYLOR, William (Ed.). Metaphors of Education. London, Heinemann Educational Books, 1984, 68-78.

JOHNSON, Mark. The body in the mind: the bodily basis of meaning, imagination, and reason. Chicago; London: The University of Chicago Press, 1987.

LAKOFF, George; JOHNSON, Mark. Metaphors we live by. London: University of Chicago Press, 2003.

LAWTON, D. Metaphor and the curriculum. In: TAYLOR, William (Ed.). Metaphors of education. London: Heinemann Educational, 1984. p. 79-90.

LiTtLEMORE, Jeannette; LOW, Graham. Figurative thinking and foreign language learning. Basingstoke; New York: Palgrave Macmillan, 2006.

LOW, Graham; LitTLEMORE; Jeannette; KOESTER, Almut. Metaphor use in three UK university lectures. Applied Linguistics, v. 29, n. 3, p. 428-455, 2008.

LiTTLEMORE, Jeannette; CHEN, Phillys; BARNDEN, John; KOESTER, Almut. Difficulties in metaphor comprehension faced by international students whose first language is not English. Applied Linguistics, v. 32, n. 4, p. 208-429, 2011.

PAIVA, Vera Menezes de Oliveira. Multimedia language learning histories. In: KALAJA, Paula; MENEZES, Vera; BARCELOS, Ana Maria F. (Ed.). Narratives of learning and teaching EFL. London: Palgrave-Macmillan, 2008. p. 199-213.

. A metonímia como processo fractal multimodal. Veredas, Juiz de For a, v. 14, n. 1, p. 7-19, 2010 .

PRAGGleJAZ GROUP. MIP: A method for identifying metaphorically used words in discourse. Metaphor and Symbol, v. 22, n. 1, p. 1-39, 2007.

Silva, Marina Morena dos Santos e. Metáforas de aprendizagem: um olhar sobre narrativas multimodais de aprendizes de língua inglesa. 2013. 115 f. Dissertação (Mestrado em Linguística Aplicada) - Faculdade de Letras, Universidade Federal de Minas Gerais, Belo Horizonte, 2013.

Stelma, Juurd H.; CAMERon, Lynne J. Intonation units in spoken interaction: developing transcription skills. Text \& Talk, v. 27, n. 3, p. 361-393, 2007.

SwEETSER, Eve. From etymology to pragmatics. New York: Cambridge University Press, 1990.

Recebido em 07/03/2016

Aceito em 05/05/2016

Pandaemonium, São Paulo, v. 19, n. 28, set.-out. 2016, p. 124-152 